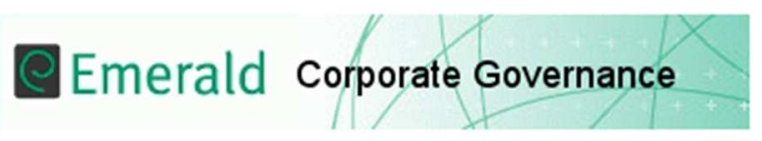

\title{
Impact of Gender Diversity on Social and Environmental Performance: Evidence from Malaysia
}

\begin{tabular}{|r|l|}
\hline Journal: & Corporate Governance \\
\hline Manuscript ID & CG-12-2015-0161.R3 \\
\hline Manuscript Type: & Original Article \\
\hline Keywords: & Women directors, Social responsibility, Environmental sustainability \\
\hline \multicolumn{2}{|}{} \\
\hline
\end{tabular}

\section{SCHOLARONE ${ }^{\text {Tx }}$ \\ Manuscripts}


Impact of Gender Diversity on Social and Environmental Performance: Evidence from Malaysia

\begin{abstract}
Purpose - This study is guided by the upper echelon theory and argues that the role of females on boards of directors may differ between cultures. In a culture where the community has a significant humane orientation, female directors may pay much more attention to the social issues of corporate sustainability rather than environmental issues. Therefore, this study differentiates between the social and environmental performances of companies to examine whether the presence of females on the boards of directors of Malaysian firms could affect social and environmental performances differently.

Design/methodology/approach - This study uses a sample of firms listed in Bursa Malaysia and develops two disclosure indices to measure social and environmental performances. Three proxies of female directors are used in the empirical models. The ordinary Least Square is used to test the hypothesis.

Findings - The empirical results suggest a positive association between social performance and the presence of female directors on the board of directors of Malaysian firms. However, no association was found between environmental performance and the presence of female directors on those boards. These results confirm the prediction of this study that the female directors of Malaysian firms pay more attention to social issues than to environmental ones.

Originality/value - This is the first study to examine the effects of the presence of female directors on Malaysian firms' boards of directors on social and environmental performance. It also contributes to the upper echelon theory by illuminating the importance of gender diversity in influencing the social and environmental behaviors of corporate leaders. The results provide the important implication that the association between a firm's social and environmental performance and gender diversity depends on the culture within which the company operates.
\end{abstract}

Keywords: Women directors; Social responsibility; Environmental sustainability 


\section{Introduction}

Prior research on gender diversity in terms of decision making shows that it can either improve the quality of decisions by introducing new perspectives and enriching the information available to the team, or hinder effective team performance by increasing divisiveness and conflict (Gilbert and Ivancevich, 2000; Kravitz, 2003; Boone and Hendriks, 2009). This may be because women and men have different leadership styles, and female directors are more participative and democratic than men (Ray, 2005). Landry et al. (2014) found that the higher the percentage of women on a firm's board of directors, the more likely the company is to appear on lists of the most admired companies, the most ethical companies, the best companies to work for, and the best corporate citizens. Harjoto et al. (2015) found that gender is consistently one of the driving factors of a firm's corporate social responsibility (CSR) performance.

The upper echelon theory suggests that a manager's demographic characteristics (such as age, education, organizational tenure, and functional background) and psychological characteristics particularly their personal values - have an impact on organizational outcomes.

Therefore, this study argues that the role of women on boards of directors may differ between cultures. In a culture where the community has a significant humane orientation ${ }^{1}$, female directors have been found to pay much more attention to social rather than environmental issues. Social issues are related to donations, supporting education, and supporting non-governmental organizations (NGOs), whereas environmental issues include recycling, waste management, water efficiency, and reduction of pollution (Rahman and Post, 2012). Some prior research (e.g., Samdahl and Robertson, 1989; Grunert and Kristensen, 1992; Diamantopoulos et al., 2003) has found that men are more concerned with environmental issues than women. Other research (e.g., Betz et al., 1989; Bernardi and Arnold, 1997) found that women are comfortable and engaged in social activities, while men are more engaged in environmental and economic activities. In interviews with Australian board members, male directors stated that they tend to welcome female directors' input on so-called "soft issues" (such as human resources, occupational health

\footnotetext{
1 "Humane orientation" is defined as "the degree to which an organization or society encourages and rewards individuals for being fair, altruistic, friendly, generous, caring, and kind to others" (House et al., 2004, p. 569).
} 
and safety, corporate donations, and ethics), but usually discount their input on technical issues (such as engineering) (EOWA, 2008).

This study, therefore, differentiates between social and environmental performance to examine whether the presence of women on Malaysian firms' boards of directors affects social and environmental performance differently. In particular, the study aims to examine the impact of the presence of a female director in Malaysian firms on environmental and social performance.

Malaysia has a relatively high collectivist culture, and has the highest score in the power distance index (Hofstede, 1994). Furthermore, within its collectivistic culture, harmony and unity are considered to be more socially desirable (Hofstede, 1991). Malaysia is also ranked first in humane orientation in the GLOBE study of 18,000 managers in 62 countries (Javidan and House, 2001).

This study offers three distinct contributions to firm performance literature in general and gender diversity research in particular. First, to the best of our knowledge, this is the first study to examine the effect of the presence of female directors on Malaysian firms' boards of directors on social and environmental performance. It adds to the literature and provides new evidence regarding the effect of gender diversity in Muslim-dominated countries (e.g., Malaysia). Second, this study reports that female directors have a better impact on social performance, but not environmental performance. This result provides additional insight on the impact of genderdiversity on firm performance; it complements the findings of other prior research on gender diversity (e.g., Adams and Ferreira, 2009; Ahern and Dittmar, 2012; Matsa and Miller, 2013). The results provide the important implication that the association between firm performance and gender diversity depends on the culture within which the company operates. This supports prior research on optimal board composition (e.g., Balsam et al., 2012). Third, other studies have found female directors to have a positive association with corporate social performance (e.g., Manner, 2010; Mallin and Michelon, 2011; Boulouta, 2013; Hafsi and Turgut, 2013; Zhang et al., 2013). However, these studies are predominantly US-centric, as they rely on the KLD's SOCRATES database that generates CSR ratings for US firms. 
The rest of this paper is organized as follows: Section 2 reviews the relevant literature and formulates the research hypothesis; Section 3 details the research design; Section 4 presents the findings; and Section 5 concludes.

\section{Literature review and hypothesis development}

Gender diversity is one aspect of board diversity. Recently, board gender diversity has become a noteworthy issue in firms. It is argued that the values of men and women differ regarding social responsibility (Post et al., 2011). Jaffee and Hyde (2000) conducted a meta-analysis research on gender differences using 160 independent samples. They found that women are more likely than men to maintain their relationships and feel responsible for others' needs. Consistently, Smith and Rogers (2000) report that women are more likely than men to act ethically and avoid violations of organizational policy. Moreover, it is suggested that women are more concerned about perceived health and environmental risks than men (Wehrymeyer and McNeil, 2000).

The US and European countries have highlighted that adding more female directors to corporate boards is regarded as an indicator of better corporate governance. In the US, the Interfaith Center on Corporate Responsibility (ICCR) and the National Association of Corporate Directors (NACD) recommend board gender quotas and racial diversity. Consistently, the Norwegian government introduced quota legislation that required both public and state owned companies to have 40\% female board representation by January 2008 (Matsa and Miller, 2013). Likewise, Spain mandated a 40\% female quota for company boards to be effective by 2015 (Campbell and Vera, 2010). Moreover, the UK, France, Germany, The Netherlands, Belgium, and Sweden are all considering the importance of mandating a gender quota in their corporate boards (GregorySmith et al., 2014).

Empirically, extensive research has been conducted in the US to examine the association between board gender diversity and firm performance. In 2009, the Securities Exchange Commission (SEC) in the US mandated new disclosure rules requiring listed firms to disclose whether they consider diversity when recruiting new directors. Despite this trend, prior research in the US reports mixed results, finding that female board directors are associated with positive, neutral, or negative firm performance. For instance, Adams and Ferreira (2009) reported that boards with female directors suffer lower director attendance problems, while also finding a 
negative association between females on the board and firm performance. Conversely, some prior research (e.g., Carter et al., 2003; Erhardt et al., 2003) has found a positive association between the percentage of female directors on the board and firm performance. However, Farrell and Hersch (2005) found that director gender has no impact on the performance of US firms.

Aside from the US, other prior research focuses on European countries. Green and Homroy (2015) used a sample from 11 European countries (Belgium, Denmark, France, Germany, Italy, The Netherlands, Norway, Spain, Sweden, Switzerland, and the UK) to examine the impact of female representation on corporate boards on firm performance. They found a positive association between percentage of female directors on the European firms' boards and firm performance. Furthermore, European countries have been investigated separately. For instance, despite the trend towards greater representation of women on corporate boards in Norway, Ahern and Dittmar (2012) found that Norwegian firms with higher female representation on corporate boards suffer losses. Similarly, Matsa and Miller (2013) found reductions in the profits of Norwegian firms with a higher female quota on corporate boards. Meanwhile, in Spain, Campbell and Vera (2010) found a significant positive relationship between board gender diversity and firm value. However, for the UK, Gregory-Smith et al. (2014) found no association between board gender diversity and firm performance.

The insignificant relationship between board gender diversity and firm performance may be rationalized on the following bases. First, for directors to add value, they should be appointed to positions in which they can influence governance and, subsequently, firm performance (Green and Homroy, 2015). Therefore, female directors can add value only if they have influencing roles within the board and are not, due to political or legal reasons, simply present to meet female quota requirements concerning corporate boards. Second, the size of the female quota needs to be sufficiently large to be influential on corporate boards. It is suggested that the mere presence of a single female director may not be sufficient to directly influence firm performance, because the minority group member is often considered as a token and may find it more difficult to speak out and be heard (Konrad et al., 2008).

In addition to the studies examining gender diversity and firm performance, there is growing research on gender diversity and corporate decision making. Based on literature on gender-based differences, women and men have different leadership styles, with female directors being more 
participative and democratic than men (Ray, 2005). Therefore, having more females on a board could encourage more open conversations and stimulate more participative communication among board members (e.g., Eagly and Johnson, 1990; Eagly et al., 2003; Nielsen and Huse, 2010). Furthermore, women are more likely than men to possess communal attributes, such as empathy with the welfare of other people, helpfulness, kindness, sympathy, sensitivity, nurturing, and gentleness (Bear et al., 2010). However, characteristics such as being assertive, ambitious, aggressive, self-confident, daring, and competitive are ascribed more strongly to men (Rudman and Glick, 2001; Nielsen and Huse, 2010).

The participative management style of female directors, combined with their attention to and consideration of the needs of others, may lead to the active involvement of women in issues of a strategic nature that concern the firm and its myriad stakeholders, such as CSR (Nielsen and Huse, 2010). Female directors are also more likely to bring a broader perspective and enable a board to better assess the needs of the firm's diverse stakeholders (Hillman et al., 2002). Therefore, having female directors may sensitize boards to CSR initiatives, and provide perspectives that can be helpful in addressing CSR issues (Bear et al., 2010). Moreover, prior research (e.g., Ibrahim and Angelidis, 1994; Williams, 2003; Marquis and Lee, 2013) contends that women are more oriented towards philanthropic performance compared to their male colleagues, who are economically oriented. Kabongo et al. (2013) demonstrate that the existence of operational diversity programs in companies is a better indicator for predicting future corporate giving than board diversity alone. Harjoto et al. (2015) found that gender is one of the driving factors of a firm's CSR performance. Post et al. (2014) found that the greater the representation of women on a firm's board, the more likely the firm is to form sustainabilitythemed alliances. Landry et al. (2014) found that the higher the percentage of women on a company's board of directors, the more likely the company is to appear on the most admired companies, the most ethical companies, the best companies to work for, and the best corporate citizens lists.

Post et al. (2011) examined the influence of women on corporate boards through the social and environmental reporting of 78 Fortune 1000 companies. They found that a board with three or more female directors is positively associated with social and environmental reporting. In an Islamic country, Kilic et al. (2015) examined the association of women on the board with the 
level of CSR reporting in Turkish banks. They found a positive association between women on the board and CSR reporting. Similarly, Dienes and Velte (2016), focusing on Germany, found a positive relationship between women on the board and CSR disclosure. Ben-Amer et al. (2015) examined the impact of female representation on the board through greenhouse gas emissions disclosure. Using the critical mass of women on the boards in Canadian listed companies, they found that the GHG emission disclosure is positively increased when there are at least three women on the board. From the above studies, it can be concluded that there is a positive association between women on the board and CSR reporting.

In the Malaysian context, several studies have examined the level of CSR reporting. These studies have found different levels of CSR disclosure. For example, Esa and Ghazali (2012) found that the level of CSR in Malaysian government-linked companies for 2007 was $27 \%$, while Othman et al. (2011) found that industrial and plantations Malaysian listed companies had only 16\% reported CSR for the same year. Furthermore, Ahmed Haji (2013) found that the level of CSR disclosure in the Malaysian listed companies for 2006 was $18 \%$, which then increased to $32 \%$ in 2009 In terms of environmental reporting, Sundarasen et al. (2016) found that the level of environmental reporting is 3.631 points out of 9 points: around $40 \%$. They also found that Malaysian companies employ social reporting, with 9.432 points out of 15 points: around $62 \%$. Furthermore, Othman et al. (2011) found that the environmental reporting reputation for Malaysian listed firms in 2007 was only 15\%, which indicates that companies' concerns over disclosing environmental information remain low. On a related topic, a study conducted by Nazli Nik Ahmed and Sulaiman (2004) examined environmental reporting in the construction and industrial sector of Malaysian listed companies for 2000. They found that the level of environmental reporting was around $28 \%$. Based on the above discussion, it can be concluded that the level of CSR reporting is low in Malaysian listed companies. However, this level of reporting has increased to some extent, especially since CSR reporting became compulsory in Malaysian listed companies in 2007 (Glass et al., 2015).

Theoretically, the upper echelon theory explicates how a manager's cognitive base influences the perceptual processes underlying their decision making (Hambrick and Mason, 1984). This theory suggests that a board of directors exercise a fundamental influence on strategic choices in their organizations and, hence, upon their outcomes (Finkelstein and Hambrick, 1990; Wiersema and 
Bantel, 1992). This theory is supported in prior research (e.g., Cyert and March, 1963; Hambrick and Mason, 1984), which reports that complex decisions are largely the outcome of behavioral factors, rather than a mechanical quest for economic optimization.

Furthermore, the upper echelon theory argues that if strategic choices have a large behavioral component, they reflect the decision-maker's cognitive base and values. Consistently, Hambrick and Mason (1984: p. 195) stated, "the manager's eventual perception of the situation combines with his/her values to provide the basis for strategic choice”. Moreover, performance quality is the product of individual characteristics congruent with a quality-oriented culture (Miron et al., 2004).

This study argues that in a culture, such as that of Malaysia, where social performance has a significant humane orientation, female directors may pay more attention to issues related to the social dimension of CSR than to other performance aspects or environmental and market place dimensions. Malaysia has a relatively high collectivist culture, and has the highest score in the power distance index (Hofstede, 1994). Furthermore, within its collectivistic cultures, harmony and unity are considered to be more socially desirable (Hofstede, 1991).

Consistent with Malaysian culture, Choi (2005) found that caring for family and friends are identified as the most important social aspects affecting women in Malaysia. Therefore, we may expect female directors in Malaysian firms to be more concerned with social issues than with environmental issues. Moreover, we can expect Malaysian firms' female directors to be more concerned with social issues than environmental issues due to the argument that sex-based biases or stereotyping by male directors might be inhibiting female directors' voices on environmental issues. Consistently, Galbreath (2011) found that women on boards are likely to encounter some resistance in decision-making processes that could limit their influence on sustainable outcomes.

To conclude, in line with the upper echelon theory, coupled with the gender-related culture of Malaysia - where women are more responsive to ethical and social issues that affect multiple stakeholders - we expect that Malaysian firms' female directors will be more concerned about social issues than environmental issues. Therefore, the following hypothesis is proposed:

\section{$\mathrm{H}_{\mathrm{a}}$ : Female directors in Malaysian firms are more likely to be concerned with social performance than environmental performance.}




\section{Research design}

\subsection{Measuring environmental (ENVI) and social (SOCIAL) performance}

Two indices are developed to measure environmental (ENVI) and social (SOCIAL) performance. Appendix A describes the procedure used to measure the environmental and social performances that are practiced by Malaysian firms. The two indices are developed based on an extensive review of relevant sources, such as KLD, GRI-G33, a CSR booklet issued by Bursa Malaysia, and some prior research (e.g., Greening and Turban, 2000; Rahman and Post, 2012). The two indices consider the popular disclosure items that are assumed to be disclosed by any company in any industry, and use of the scale appears to be a common practice. They could also be replicated easily because they focus on meaningful environmental and social practices. In our scoring approach, a zero value is given for a firm not disclosing information about its social and environmental performances, and a score of 1 is given for a firm disclosing specific information about its social and environmental performances. For instance, if a company discloses information about the existence of donation in general, a score of 1 is given to this company; consequently, scores are added as the amount of donation is disclosed. Furthermore, a score of 1 is given where a company discloses general information about its engagement with stakeholders; consequently, other scores are added if the company specifies the types of stakeholders and the ways of engagement.

To assess the reliability of the coding methodology, all the coding steps were repeated eight months after scoring all the sample companies. The coding steps are repeated for $30 \%$ of the sample and we obtained above 90\% score consistency. Furthermore, the current study adopts an analytical analysis methodology to validate the scores of social and environmental performances. ${ }^{2}$ The study, therefore, empirically examined the association between social and environment performance scores and several factors that have been identified in prior research as determinates of social and environmental performances. The current study, as reported in the empirical analysis in section 4.3, finds that associations exist between social and environmental

\footnotetext{
${ }^{2}$ The analytical validity method suggests that the score is considered valid if it is associated with several firmspecific characteristics identified in prior research (Botosan, 1997; Hassanein and Hussainey, 2015).
} 
performance scores and several determinates of social and environmental performances. These factors include: firm size, size of the board of directors, and the percentage of institutional ownership. This result adds validity to the social and environmental performance scores.

\subsection{Empirical models}

To test our hypothesis, the study used three different measures to represent the gender of female directors. First, GENDER, a dummy variable that takes the value of 1 if there is female director in the board and 0 otherwise. Second, GENDERPCT, the percentage of female directors on the corporate board. Third, BLAU, the Blau's (1977) index of heterogeneity (1- $\left.\sum \rho \_\mathfrak{i}^{\wedge} 2\right)$, where $\rho \_\mathfrak{i}^{\wedge} 2$ is the proportion of group members in each of the $i$ number of categories, which are female or male. The range of the index is dependent upon the number of categories, where the number ranges from 0 to $(i-1) / i^{3}$

Furthermore, the study controls for some firm-specific characteristics that have been identified as determinants of social and environmental performances in prior research (e.g., Amran and Devi, 2008; Esa and Ghazali, 2012; Boulouta, 2013; Rebeiz, 2015). These variables include: firm size (SIZE), measured as the natural logarithm of market capitalization at the end of the year; firm leverage (LEVERAGE), measured as ratio of total debt to total assets; firm profitability (ROA), measured as return on assets ratio; board size (BOARDN), measured as the number of directors on the board; auditor type (AUDITOR), which takes the value of 1 if the company is audited by one of the Big Four audit firms and 0 otherwise ${ }^{4}$; book to market value (BTM), measured as the ratio of book value of firm equity to its market value at year-end; and, finally, institutional ownership (IO), measured as the percentage of institutional ownership. Moreover, the study uses industry-fixed effects to control for industry specific characteristics that may affect environmental and social performances (Clements et al., 2015; Hassanein and Hussaieny, 2015). Equations (1) \& (2) summarize the empirical models. Table 1 elaborates the definitions of variables.

\footnotetext{
${ }^{3}$ In our sample, Blau index values for gender ranged from 0 to 0.48 , reflecting the entire feasible range. Although we do not explicitly categorize index values into "low", "moderate", and "high" heterogeneity here. The index values represented a continuous measure. Blau index values of 0.20 or above would reflect relatively high heterogeneity for this sample.

${ }^{4}$ The Big Four are the four largest international professional services networks, offering audit, assurance, tax, consulting, advisory, actuarial, corporate finance, and legal services, comprising PwC, Deloitte, Ernst \& Young, and KPMG.
} 
SOCIAL $=\beta_{0}+\beta_{1}$ FEMALE DIRECTORS $+\beta_{2}$ SIZE $+\beta_{3}$ LEVERAGE $+\beta_{4}$ ROA + $\beta_{5}$ BOARDN $+\beta_{6}$ AUDITOR $+\beta_{7}$ BTM $+\beta_{8}$ IO + Industry-fixed effect $+\varepsilon$

\section{ENVI $=\beta_{0}+\beta_{1}$ FEMALE DIRECTORS $+\beta_{2}$ SIZE $+\beta_{3}$ LEVERAGE $+\beta_{4}$ ROA $+\beta_{5}$ BOARDN \\ $+\beta_{6}$ AUDITOR $+\beta_{7}$ BTM $+\beta_{8}$ IO +Industry-fixed effect $+\varepsilon$

Where:

$\begin{array}{ll}\boldsymbol{\beta}_{\mathbf{0}} & \text { The regression intercept } \\ \boldsymbol{\beta}_{\mathbf{1}} \ldots \boldsymbol{\beta}_{\mathbf{8}} & \text { The regression coefficients } \\ \boldsymbol{\varepsilon} & \text { The error term }\end{array}$

[Insert Table 1 here]

\subsection{Sample selection and data collection}

This study aims to examine the impact of the presence of female directors on environmental and social performances. The sample comprises firms listed on the main market in Bursa Malaysia during 2009. The analysis focuses on these companies because data was available for a large number of firms that have analyst coverage. Following prior research (Hussainey et al., 2003), companies under analysts' coverage disclose more social and environmental information. In 2005, Bursa Malaysia launched the Capital Market Development Fund-Bursa Research Scheme (CBRS) reports. In June 2008, a total of 303 listed firms participated in the CBRS. The main aim of the CBRS is to enhance research analysts' coverage of stocks listed on Bursa Malaysia and to provide investors with more information to facilitate their investment decisions. Thus, the sample for this study was compiled from companies that are included in the CBRS, which are under analysts' coverage, and that also have data that fulfills the purposes of this study.

The annual reports were read carefully to identify the environmental and social performance items. Annual reports were collected from companies' official websites. The number of female directors, auditor type, and total number of board representatives were collected manually from companies' annual reports. All financial data was collected from the DataStream Thomson Reuters database. 


\section{Findings \\ 4.1 Descriptive statistics}

The descriptive statistics of the variables are exhibited in Table 2. The ENVI score ranges from 0 to 7 points, with an average value of 1.414 (approximately 20\%). This is similar to the level of environmental reporting in 2006 (Ahmed Haji, 2013). The SOCIAL score ranges from 0 to 5 points, with an average value of 1.361 points (approximately 27\%). These scores are low compared to the maximum scores. These average scores of ENVI and SOCIAL are consistent with a Bursa Malaysia study conducted in 2007, which finds in CSR whereby two thirds were rated as average, below average, or poor (less than 15\% according to Othman et al., 2011). However, it is argued that the level of environmental reporting is increasing over time (Sundarasen et al., 2016).

The descriptive statistics also indicate that $45.9 \%$ of Malaysian companies have at least one female director. Slightly more than two-thirds of the sample firms are audited by one of the Big Four auditing firms. The average BTM is 1.5 times. On average, the sample firms have a $22 \%$ debt to asset ratio, and an ROA of approximately $7 \%$ in the fiscal year 2009 . The average number of board members is eight, and the average percentage of institutional ownership is around $22 \%$.

\section{[Insert Table 2 here]}

\subsection{Correlation analysis}

The Pearson correlation matrix is used to measure the direction of the linear association between any pair of variables. Table 3 shows the correlation matrix for all variables. It provides preliminary evidence that female director measures (GENDERN, GENDERPCT and BLAU) are not statistically correlated with environmental performance (ENVI), However, GENDERN is statistically positively correlated with social performance (SOCIAL).

In addition, the ENVI score is statistically correlated with firm size (SIZE), size of the board of directors (BOARDN), firm profitability (ROA), and auditor type (AUDITOR). Furthermore, the SOCIAL score is statistically correlated with firm size (SIZE), size of the board of directors 
(BOARDN), and institutional ownership (IO). Following prior research on disclosure (e.g., Hassanein and Hussainey, 2015), these results ensure the validity of the ENVI and SOCIAL scores.

In addition to measuring the strength and direction of the linear association between any pair of variables, the Pearson coefficient may also be used to diagnose multi-collinearity among independent variables. Table 3 demonstrates that the Pearson correlation coefficients among all independent variables are relatively low: less than $0.80,{ }^{5}$ suggesting that there is no concern over multi-collinearity.

\subsection{Empirical results}

[Insert Table 3 here]

Multivariate analysis was conducted for Models $1 \& 2$ using three different measures of female representatives in each model. Table 4 reports the multivariate results of Models $1 \& 2$ using the three proxies of female representative. Columns 1, 2, and 3 provide the estimation of Model 1; the effect of a female representative (using the three proxies) on social performance (SOCIAL). However, columns 4, 5, and 6 provide the estimation of Model 2; the effect of a female representatives (using the three proxies) on environmental performance (ENVI). The $P$ statistical values are presented in parentheses and are based on industry-fixed effect.

The proposed models are statistically significant at $1 \%$ significance level $(p$-value $<.01)$ and the adjusted $\mathrm{R}^{2}$ values range between $19.5 \%$ and $22.8 \%$. These values imply a good overall fit of the models, which indicates that the models explain some variations in social and environmental performances. The low values of adjusted $\mathrm{R}^{2}$ are the norm in similar disclosure studies (see, for example, Gul and Leung, 2004; Amran et al., 2014; Hassanein and Hussainey, 2015).

The coefficients of the three proxies of female director are 0.445 ( $p$-value $=0.006), 1.51(p$-value $=0.033)$, and $0.772(p$-value $=0.100)$ respectively. These results suggest a statistically positive

\footnotetext{
${ }^{5}$ Tabachnick and Fidell (2007) stated that multi-collinearity among independent variables results in the problem of assessing the importance of each variable in the regression. Therefore, it is necessary to compare the total relationship of the independent variables with the dependent variable (correlation) and the correlations of the independent variables with each other (in the correlation matrix) (Tabachnick and Fidell, 2007). The Pearson correlation matrix is the initial tool to detect multi-collinearity. Gujarati and Porter (2009) indicated that variables are highly correlated if the correlation is $>0.80$.
} 
relationship between social performance and the three proxies of female directors, meaning that social performance is positively associated with the presence of female directors on Malaysian firms' board of directors. The results are consistent with the arguments that there is a link between presence of female directors and social initiatives, and that females are more likely to be more sensitive to social needs. Ibrahim and Angelidis (1994) reported that women are less economically driven and more philanthropically oriented than men. They are also consistent with Jia and Zhang (2012), who found that there is a positive relationship between ratios of female directors and philanthropic disaster response.

Conversely, the coefficients of the three proxies of female director on environmental performance $($ ENVI) are -.175 $(p$-value $=.446),-.177(p$-value $=.264)$, and -1.205 $(p$-value $=$ .108). These results suggest that there is no relationship between environmental performance and proxies of female directors, meaning that environmental performance is not associated with the presence of female directors on Malaysian firms' boards of directors. These results are consistent with the study of Amran et al. (2014) that was conducted in Asian countries: it found no significant relationship between sustainability reporting quality and female directors. They are also consistent with Galbreath (2011), who found that female directors are not significantly associated with environmental quality. However, these results are not consistent with Braun (2010), who reported that women have a stronger environmental attitude and commitment to green entrepreneurship programs then men.

Theoretically, the results are line with our prediction and argument that in a culture such as that in Malaysia, where social performance has a significant humane orientation, female directors pay much more attention to issues related to the social aspect of CSR than to other performance dimensions, such as environmental and market place dimensions. These results may be rationalized from three different perspectives. First, Malaysia is ranked first in humane orientation (Javidan and House, 2001), and is considered to be socially desirable (Hofstede, 1991). Thus, Malaysian women are much more concerned with social issues than environmental issues. Second, Galbreath (2011) argued that sex-based biases or stereotyping by male directors might be inhibiting female directors' voices on environmental issues. Consistently, he found that women on boards are likely to encounter some resistance in decision-making processes that could limit their influence on sustainable outcomes. Thus, Malaysian female directors may face 
this problem, and, consequently, may be more concerned with social issues than environmental issues. Another explanation might be that in countries (such as Malaysia) that are experiencing higher growth rates in their GDP, the female directors are more likely to provide priority to social needs than to environmental ones (Beckerman, 1992).

Overall, the results of this study support the current study's expectation based on the upper echelon theory. Specifically, they support the idea that organizational outcomes are reflections of the culture, values, and cognitive biases of powerful actors within the organization.

In terms of control variables, the study finds that social performance (SOCIAL) is positively associated with firm size (SIZE), size of board of directors (BOARDN) ${ }^{6}$, and institutional ownership (IO). However, the study also finds that environmental performance (ENVI) is positively (negatively) associated with firm size, size of board of directors, and IO. These results suggest that firm performances - e.g., social and environmental - are associated with its characteristics and its corporate governance mechanisms.

\section{[Insert Table 4 here]}

\section{Conclusion}

This study is the first to examine the effect of the presence of females on Malaysian firms' boards of directors on social and environmental performances. The study is based on the expectation of the upper echelon theory that organizational outcomes are reflections of the values and cognitive biases of powerful actors within the organization. In particular, this study argues that in a culture such as that in Malaysia, where social performance has a significant humane orientation, female directors may pay much more attention to issues related to the social aspect of CSR than to other performance dimensions, such as economic, environmental, and market place dimensions.

The study uses a sample from Malaysian firms and develops two disclosure indices to measure social and environmental performances. The empirical results suggest a positive association between social performance and the presence of female directors on the board of directors in

\footnotetext{
${ }^{6}$ The study finds that size of board of directors (BOARDN) is not positively associated with women in the board when of the board are measured as dummy variables. However, the results are statistically significant under the two other proxies.
} 
Malaysian firms. However, no association exists between environmental performance and the presence of female directors in Malaysian firms. Overall, the results support the theoretical expectation based on the upper echelon theory, that organizational outcomes are reflections of the culture, values, and cognitive biases of powerful actors within the organization.

The study provides implications for enforcing female quotas on corporate boards of directors. Moreover, the study's results provide useful insight into the impact of female directors on social performance. Consequently, in firms with strong governance, enforcing gender quotas on the board of directors could ultimately enhance social performance. This may be because greater gender diversity on the board leads to greater monitoring of the firm. Furthermore, the results provide the important implication that the association between social and environmental performances and gender diversity depends on the culture within which the company operates. Therefore, the study's results call for more research to facilitate understanding of whether culture affects the orientation of female directors on the board of directors. The results also suggest that, in Malaysia, female directors may pay much more attention to social performance than to environmental performance. Therefore, future case studies could reveal more interesting insights into the nature and factors that influence the decision-making process of the board of directors.

This study has some limitations that have to be considered as potential avenues for future research. First, the study focuses only on Malaysian firms. Other countries, however, could have different cultures that may affect the results. Therefore, it would be interesting to expand into other countries worldwide (e.g., Gulf countries). Second, extending the current research design to include other countries may be an area of interest for future research. This may help in observing the impact of country characteristics (e.g., inflation, legal system, and political factors) on gender diversity. Third, the study focuses on two dimensions of CSR: social and environmental. Future research may focus on other comprehensive dimensions of performance. Fourth, in terms of measurement of social and environmental disclosure, the environmental and social index captures useful information to that similarly used in prior research, and is based on unsubstantiated CSR information provided in annual reports: i.e., there is no thirdparty assurance. Moreover, the disclosures in the annual reports may not capture all of the facets of CSR performance undertaken by the firm. Finally, future research could investigate whether the proportion of women on the board of directors could affect the decision-making process. 


\section{ACKNOWLEDGMENTS}

** We would like to thank Dr. Gabriel Eweje and Dr Rosa Caiazza, (the editor of Corporate Governance: The international journal of business in society), and the anonymous referees for their helpful comments and suggestions. We would also like to thank the participants at the EuroMed Academy of Business specialized conference in HR practices, strategic and entrepreneurial challenges - Academic and Practitioners' Views (Paris, 2015) - for their valuable feedback. We are also grateful for the financial support provided by Qatar University. 


\section{References}

Adams, R. B., and Ferreira, D. (2009). Women in the boardroom and their impact on governance and performance. Journal of financial economics, Vol. 94 No. 2, pp. 291-309.

Ahern, K. R., and Dittmar, A. K. (2012). The changing of the boards: The impact on firm valuation of mandated female board representation. Quarterly Journal of Economics, Vol.127 No. 1, pp. 137-197.

Ahmed Haji, A. (2013). Corporate social responsibility disclosures over time: evidence from Malaysia. Managerial auditing journal, Vol. 28 No. 7, pp. 647-676.

Amran, A., and Devi, S. (2008). The impact of government and foreign affiliate influence on corporate social reporting: The case of Malaysia. Managerial Auditing Journal, Vol. 23 No. 4, pp. 386-404.

Amran, A., Lee, S. P., and Devi, S. (2014). The influence of governance structure and strategic corporate social responsibility toward sustainability reporting quality. Business Strategy and the Environment, Vol. 23 No. 4, pp. 217-235.

Balsam, S., Puthenpurackal, J., and Upadhyay, A. (2012). The impact of an outside board chair on firm value. Working paper.

Bear, S., Rahman, N., and Post, C. (2010). The impact of board diversity and gender composition on corporate social responsibility and firm reputation. Journal of Business Ethics, Vol. 97 No. 2, pp. 207-221.

Beckerman, W. (1992). Economic growth and the environment: Whose growth? Whose environment? World Development, Vol. 20, pp. 481-496.

Ben-Amar, W., Chang, M., and McIlkenny, P. (2015). Board Gender Diversity and Corporate Response to Sustainability Initiatives: Evidence from the Carbon Disclosure Project. Journal of Business Ethics, pp. 1-15.

Bernardi, R. A., and Arnold Sr, D. F. (1997). An examination of moral development within public accounting by gender, staff level, and firm. Contemporary Accounting Research, Vol. 14 No. 4, pp. 653.

Betz, M., O'Connell, L., and Shepard, J. M. (1989). Gender differences in proclivity for unethical behavior. Journal of Business Ethics, Vol. 8 No. 5, pp. 321-324.

Blau, P. M. (1977). Inequality and heterogeneity: A primitive theory of social structure (Vol. 7), Free Press, New York.

Boone, C., and Hendriks, W. (2009). Top management team diversity and firm performance: moderators of functional-background and locus-of-control diversity. Management Science, Vol. 55 No. 2, pp. 165-180. 
Botosan, C. (1997). Disclosure level and the cost of capital. The Accounting Review, Vol. 72, pp. 323-350.

Boulouta, I. (2013). Hidden connections: The link between board gender diversity and corporate social performance. Journal of Business Ethics, Vol. 113 No. 2, pp. 185-197.

Braun, P. (2010). Going green: women entrepreneurs and the environment. International Journal of Gender and Entrepreneurship, Vol. 2 No. 3, pp. 245-259.

Campbell, K., and Vera, A. M. (2010). Female board appointments and firm valuation: Short and long-term effects. Journal of Management \& Governance, Vol. 14 No. 1, pp. 37-59.

Carter, D. A., Simkins, B. J., and Simpson, W. G. (2003). Corporate governance, board diversity, and firm value. Financial review, Vol. 38 No. 1, pp. 33-53.

Choi, B. C. (2005). An international comparison of women's occupational health issues in the Philippines, Thailand, Malaysia, Canada, Hong Kong and Singapore: the CIDA-SEAGEP Study. Occupational Medicine, Vol. 55 No. 7, pp. 515-522.

Clements, C., Neill, J., and Wertheim, P. (2015). Multiple directorships, industry relatedness, and corporate governance effectiveness", Corporate Governance, Vol. 15 No. 5, pp. 590 -606 .

Cyert, R. M., and March, J. G. (1963). A behavioral theory of the firm. Englewood Cliffs, NJ, 2.

Diamantopoulos, A., Schlegelmilch, B., Sinkovics, R., and Bohlen, M. (2003). Can sociodemographics still play a role in profiling green consumers? A review of the evidence and an empirical investigation. Journal of Business research, Vol. 56 No. 6, pp. 465-480.

Dienes, D., and Velte, P. (2016). The Impact of Supervisory Board Composition on CSR Reporting. Evidence from the German Two-Tier System. Sustainability, Vol. 8 No. 1, pp. 63.

Eagly, A. H., and Johnson, B. T. (1990). Gender and leadership style: A metaanalysis. Psychological Bulletin, Vol. 108 No. 2, pp. 233.

Eagly, A. H., Johannesen-Schmidt, M. C., and van Engen, M. L. (2003). Transformational, transactional, and laissez-faire leadership styles: a meta-analysis comparing women and men. Psychological Bulletin, Vol. 129 No. 4, pp. 569.

EOWA. (2008). A gender in the boardroom. Equal Opportunity for Women in the Workplace Agency (EOWA): Canberra.

Erhardt, N. L., Werbel, J. D., and Shrader, C. B. (2003). Board of director diversity and firm financial performance. Corporate governance: An international review, Vol. 11 No. 2, pp. 102-111. 
Esa, E., and Ghazali, N. (2012). Corporate social responsibility and corporate governance in Malaysian government-linked companies. Corporate Governance: The international journal of business in society, Vol. 12 No. 3, pp. $292-305$.

Farrell, K. A., and Hersch, P. L. (2005). Additions to corporate boards: the effect of gender. Journal of Corporate finance, Vol. 11 No. 1, pp. 85-106.

Finkelstein, S., and Hambrick, D. C. (1990). Top-management-team tenure and organizational outcomes: The moderating role of managerial discretion. Administrative science quarterly, pp. 484-503.

Galbreath, J. (2011) Are there gender-related influences on corporate sustainability? A study of women on boards of directors. Journal of Management and Organization, Vol. 17 No. 1, pp. 17- 38 .

Gilbert, J. A., and Ivancevich, J. M. (2000). Valuing diversity: A tale of two organizations. The Academy of Management Executive, Vol. 14 No. 1, pp. 93-105.

Glass, C., Cook, A., and Ingersoll, A. R. (2015). Do Women Leaders Promote Sustainability? Analyzing the Effect of Corporate Governance Composition on Environmental Performance. Business Strategy and the Environment, Early view, DOI: $10.1002 /$ bse. 1879

Green, C., and Homroy, S. (2015). Female directors, key committees, and firm performance.

Working paper. Lancaster University, UK. Available: https://www.lancaster.ac.uk/media/lancaster-university/contentassets/documents/lums/economics/working-papers/LancasterWP2015 023.pdf

Greening, D. W., and Turban, D. B. (2000). Corporate social performance as a competitive advantage in attracting a quality workforce. Business and Society, Vol. 39 No. 3, pp. 254280.

Gregory-Smith, I., Main, B. G., and O'Reilly, C. A. (2014). Appointments, pay and performance in UK boardrooms by gender. The Economic Journal, Vol. 124 No. 574, pp. F109-F128.

Grunert, S. C., and Kristensen, K. (1992). The green consumer: some Danish evidence. Marketing for Europe-Marketing for the Future, pp. 525-539.

Gujarati, D. N. and Porter, D. C. (2009). Basic Econometrics. Fifth Edition, McGraw Hill, New York.

Gul, F. A., and Leung, S. (2004). Board leadership, outside directors' expertise and voluntary corporate disclosures. Journal of Accounting and public Policy, Vol. 23 No. 5, pp. 351379.

Hafsi, T., and Turgut, G. (2013). Boardroom diversity and its effect on social performance: Conceptualization and empirical evidence. Journal of Business Ethics, Vol. 112 No. 3, pp. 463-479. 
Hambrick, D. C., and Mason, P. A. (1984). Upper echelons: The organization as a reflection of its top managers. Academy of management review, Vol. 9 No. 2, pp. 193-206.

Harjoto, M., Laksmana, I., and Lee, R. (2015). Board diversity and corporate social responsibility. Journal of Business Ethics, Vol. 132 No. 4, pp. 641-660.

Hassanein, A. and Hussainey, K. (2015). Is forward-looking financial disclosure really informative? Evidence from UK narrative statements. International Review of Financial Analysis, Vol. 41, pp. 52 - 61.

Hillman, A. J., Cannella, A. A., and Harris, I. C. (2002). Women and racial minorities in the boardroom: how do directors differ? Journal of Management, Vol. 28 No. 6, pp. 747763.

Hofstede, G. (1994). The business of international business is culture. International Business Review, Vol. 3 No. 1, pp. 1-14.

Hofstede, G. (1991). Cultures and organisations-software of the mind: intercultural cooperation and its importance for survival. McGraw-Hill, New York.

House, R.J., Hanges, P.J., Javidan, M., Dorfman, P. and Gupta, V. (2004). Culture, Leadership, and Organizations: The GLOBE Study of 62 Societies, Sage Publications: Thousand Oaks, CA.

Hussainey, K., Schleicher, T., and Walker, M. (2003). Undertaking large-scale disclosure studies when AIMR-FAF ratings are not available: the case of prices leading earnings. Accounting and Business Research, Vol. 33 No. 4, pp. 275-294.

Ibrahim, N. A., and Angelidis, J. P. (1994). Effect of board members' gender on corporate social responsiveness orientation. Journal of Applied Business Research, Vol. 10 No. 1, pp. 3540.

Jaffee, S., and Hyde, J. S. (2000). Gender differences in moral orientation: a metaanalysis. Psychological bulletin, Vol. 126 No. 5, pp. 703.

Javidan, M., and House, R. J. (2001). Cultural acumen for the global manager: Lessons from Project GLOBE. Organizational dynamics, Vol. 29 No. 4, pp. 289-305.

Jia, M., and Zhang, Z. (2012). Women on boards of directors and corporate philanthropic disaster response. China Journal of Accounting Research, Vol. 5 No. 1, pp. 83-99.

Kabongo, J. D., Chang, K., and Li, Y. (2013). The impact of operational diversity on corporate philanthropy: An empirical study of US companies. Journal of Business Ethics, Vol. 116 No. 1, pp. 49-65.

Kilıç, M., Kuzey, C., and Uyar, A.and. (2015). The impact of ownership and board structure on corporate social responsibility (CSR) reporting in the Turkish banking industry. 
Corporate Governance: The International Journal of Business in Society, Vol. 15 No. 3, pp. 357 - 374 .

Konrad, A. M., Kramer, V., and Erkut, S. (2008). Critical mass: The impact of three or more women on corporate boards. Organizational Dynamics, Vol. 37 No. 2, pp. 145-164.

Kravitz, D. A. (2003). More women in the workplace: is there a payoff in firm performance? The Academy of Management Executive, Vol. 17 No. 3, pp.148-149.

Landry, E. E., Bernardi, R. A., and Bosco, S. M. (2014). Recognition for sustained corporate social responsibility: female directors make a difference. Corporate Social Responsibility and Environmental Management, Vol. 23, No. 1, pp. 27-36

Mallin, C. A., and Michelon, G. (2011). Board reputation attributes and corporate social performance: An empirical investigation of the US best corporate citizens. Accounting and Business Research, Vol. 41 No. 2, pp. 119-144.

Manner, M. H. (2010). The impact of CEO characteristics on corporate social performance. Journal of business ethics, Vol. 93 No. 1, pp. 53-72.

Marquis, C., and Lee, M. (2013). Who is governing whom? Executives, governance, and the structure of generosity in large US firms. Strategic Management Journal, Vol. 34 No. 4, pp. $483-497$.

Matsa, D. A., and Miller, A. R. (2013). A female style in corporate leadership? Evidence from quotas. Evidence from Quota. American Economic Journal: Applied Economics, Vol. 5 No. 3, pp. 136-69.

Miron, E., Erez, M., and Naveh, E. (2004). Do personal characteristics and cultural values that promote innovation, quality, and efficiency compete or complement each other?. Journal of organizational behavior, Vol. 25 No. 2, pp. 175-199.

Nazli Nik Ahmad, N., and Sulaiman, M. (2004). Environment disclosure in Malaysia annual reports: a legitimacy theory perspective. International Journal of Commerce and Management, Vol. 14 No. 1, pp. 44-58.

Nielsen, S., and Huse, M. (2010). The contribution of women on boards of directors: Going beyond the surface. Corporate Governance: An International Review, Vol. 18 No. 2, pp. $136-148$.

Othman, S., Darus, F., and Arshad, R. (2011). The influence of coercive isomorphism on corporate social responsibility reporting and reputation. Social Responsibility Journal, Vol. 7 No. 1, pp. 119-135.

Post, C., Rahman, N., and Rubow, E. (2011). Green governance: Boards of directors' composition and environmental corporate social responsibility. Business \& Society, Vol. 50 No. 1, pp. 189-223. 
Post, C., Rahman, N., and McQuillen, C. (2014). From board composition to corporate environmental performance through sustainability-themed alliances. Journal of Business Ethics, Vol. 130 No. 2, pp. 1-13.

Rahman, N., and Post, C. (2012). Measurement issues in environmental corporate social responsibility (ECSR): Toward a transparent, reliable and construct valid instrument. Journal of Business Ethic, Vol. 105, pp. 307-319.

Ray, D. M. (2005). Corporate boards and corporate democracy. Journal of Corporate Citizenship, No. 20, pp. 93-105.

Rebeiz, K. (2015). Boardroom's independence and corporate performance: the ever-elusive conundrum. Corporate Governance, Vol. 15 No. 5, pp. 747 - 758

Rudman, L. A., and Glick, P. (2001). Prescriptive gender stereotypes and backlash toward agentic women. Journal of social issues, Vol. 57 No. 4, pp. 743-762.

Samdahl, D. M., and Robertson, R. (1989). Social determinants of environmental concern specification and test of the model. Environment and behaviour, Vol. 21 No. 1, pp. 5781.

Smith, A., and Rogers, V. (2000). Ethics-related responses to specific situation vignettes: Evidence of gender-based differences and occupational socialization. Journal of Business Ethics, Vol. 28 No. 1, pp. 73-85.

Sundarasen, S. D., Je-Yen, T., and Rajangam, N. (2016). Board Composition and Corporate Social Responsibility in an Emerging Market. Corporate Governance: The International Journal of Business in Society, Vol. 16 No. 1, pp. 35 - 53

Tabachnick, B., and Fidell, L. (2007). Using multivariate statistics. Fifth Edition, Pearson Education Inc., London.

Wehrmeyer, W., and McNeil, M. (2000). Activists, pragmatists, technophiles and tree-huggers? Gender differences in employees' environmental attitudes. Journal of Business Ethics, Vol. 28 No. 3, pp. 211-222.

Wiersema, M. F., and Bantel, K. A. (1992). Top management team demography and corporate strategic change. Academy of Management journal, Vol. 35 No. 1, pp. 91-121.

Williams, R. J. (2003). Women on corporate boards of directors and their influence on corporate philanthropy. Journal of Business Ethics, Vol. 42 No. 1, pp. 1-10.

Zhang, J. Q., Zhu, H., and Ding, H. B. (2013). Board composition and corporate social responsibility: An empirical investigation in the post Sarbanes-Oxley era. Journal of business ethics, Vol. 114 No. 3, pp. 381-392. 
Table 1.

Summary of variables: Definitions and measurements

\begin{tabular}{|c|c|c|}
\hline Definition & Acronym & Operationalization \\
\hline $\begin{array}{l}\text { Environmental } \\
\text { performance }\end{array}$ & ENVI & Environmental performance as measured in appendix A \\
\hline Social performance & SOCIAL & Social performance as measured in appendix A \\
\hline Female directors & $\begin{array}{l}\text { GENDER } \\
\text { GENDERPCT } \\
\text { BLAU }\end{array}$ & $\begin{array}{l}\text { Three measures are used: First: GENDER, a dummy } \\
\text { variable that takes the value of } 1 \text { if there is female director } \\
\text { in the board and } 0 \text { otherwise. Second: GENDERPCT, } \\
\text { percentage of female directors in the corporate board. } \\
\text { Third: } B L A U \text {, the Blau's (1977) index of heterogeneity ( } 1 \text { - } \\
\left.\sum \rho \rho^{\wedge} 2\right) \text {. }\end{array}$ \\
\hline
\end{tabular}

Is the log of Market capitalization at the end of the year.

Firm size (\$) SIZE Market capitalization is calculated as the number of outstanding shares at the year-end multiplied by the average market value of the share over 12 months.

Firm leverage (\%) LEVERAGE Total debt to total assets ratio.

Firm profitability ROA Return on assets ratio.

(\%)

Board size $\quad$ BOARDN Number of directors on the corporate board

$\begin{array}{ll}\text { Auditor type } & \text { AUDITOR } \\ \text { one of the Big Four audit firms and } 0 \text { otherwise. }\end{array}$

Book to Market $\quad$ BTM
value $(\%)$

Institutional The percentage of total shares held by institutional ownership (\%) investor. 
Industry fixed effect Industry-fixed effect

Dummy variable for each industry in the sample.

This table provides the definitions and measurements of variables in Models (1) \& (2). Manual content analysis technique is used to identify social and environmental performance items. The number of female directors, auditor type, and total number of board representatives are collected manually from companies' annual reports. All financial data is collected from the DataStream Thomson Reuters database.

\section{Table 2.}

Descriptive statistics

\begin{tabular}{lllll}
\hline & Minimum & Maximum & Mean & Std. Deviation \\
\hline ENVI (scores) & 0.000 & 7.000 & 1.414 & 1.706 \\
SOCIAL (scores) & 0.000 & 5.000 & 1.361 & 1.117 \\
GENDER (Dummy) & 0.000 & 1.000 & 0.459 & 0.500 \\
GENDERPCT (\%) & 0.000 & 0.500 & 0.084 & 0.111 \\
BLAU (Index) & 0.000 & 0.480 & 0.131 & 0.148 \\
SIZE (Log) & 2.415 & 7.541 & 5.501 & 0.726 \\
BOARDN (N) & 3.000 & 14.000 & 8.135 & 1.972 \\
LEVERAGE (\%) & 0.000 & 0.645 & 0.218 & 0.167 \\
ROA (\%) & -0.139 & 0.528 & 0.066 & 0.074 \\
AUDITOR (Dummy) & 0.000 & 1.000 & 0.699 & 0.460 \\
BTM (\%) & -0.045 & 12.831 & 1.504 & 1.540 \\
IO (\%) & 0.000 & 92.000 & 21.859 & 24.424 \\
\hline N & 133 & & & \\
\hline
\end{tabular}

This table reports the descriptive statistics of all variables.

Table (1) provides the definitions and measurements of all variables. 
3 Table 3.

5 Pearson Correlation Matrix

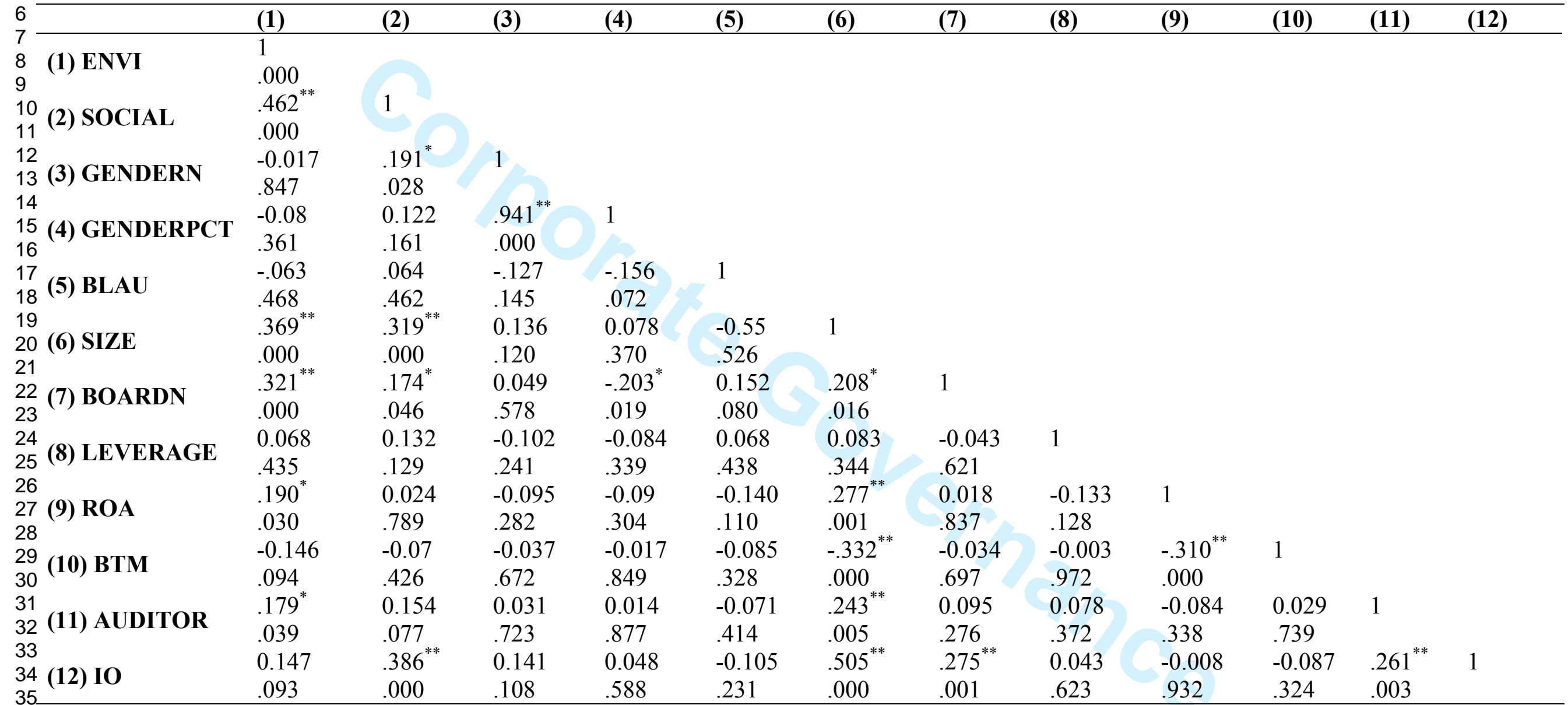

$36 * * \& *$ indicates that Correlation is significant at the $0.01 \& 0.05$ levels (2-tailed).

37 This table reports the Pearson Correlation Matrix.

38 Table (1) provides the definitions and measurements of all variables. 


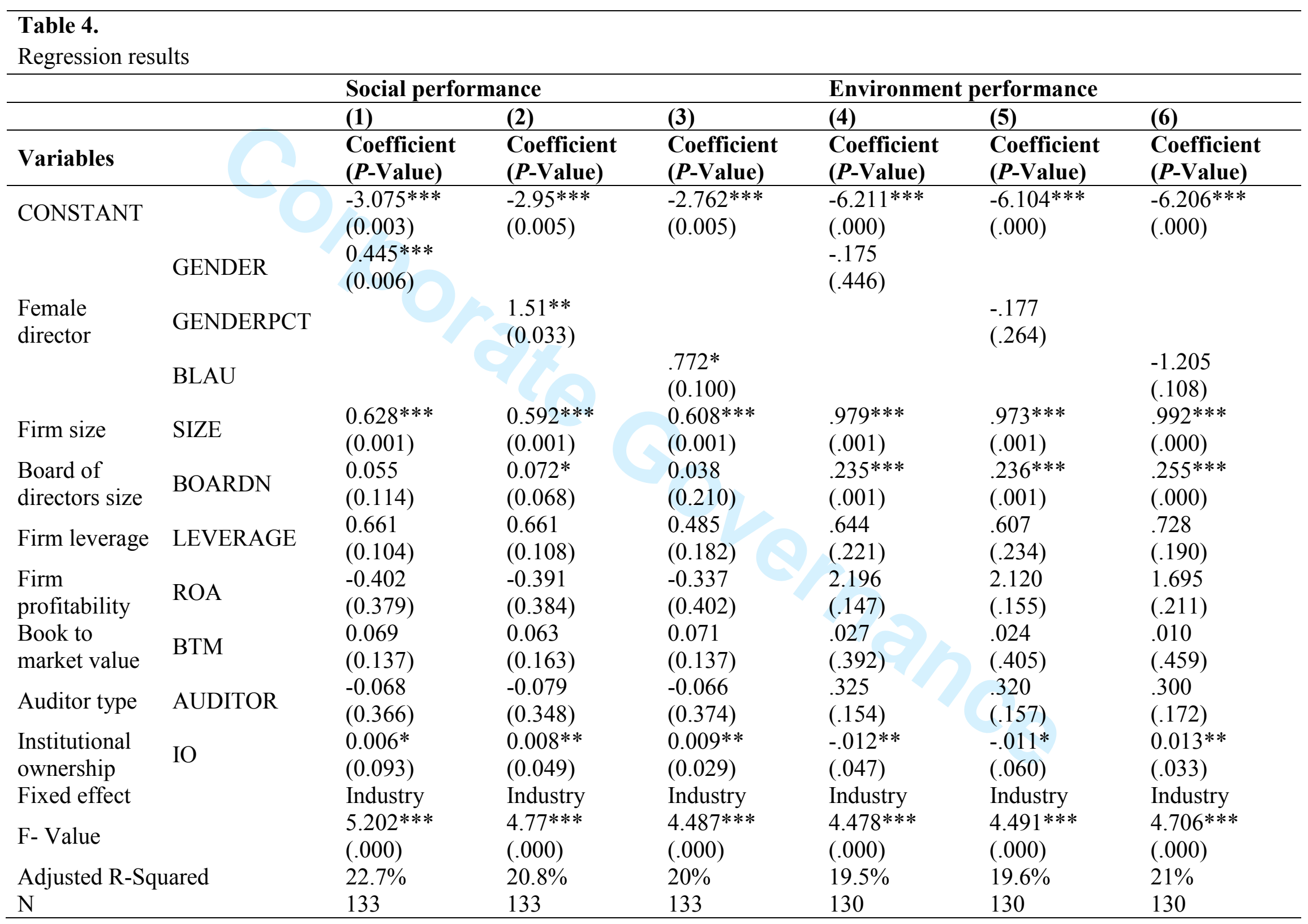


$*, * * \& * * *$ Indicate significance at $0.1,0.05 \& 0.01$, respectively.

This table reports the regression results for Models $1 \& 2$. Three measures are used for female directors.

Table (1) provides the definitions and measurements of all variables. 


\section{Appendix A \\ The environmental and social index and scoring procedures \\ The paper relies on an index we developed by using a dichotomous scoring methodology. We follow most of the research in the stream of disclosure studies that employ a similar methodology. Moreover, we ensured that the items were very common practices that no firm can avoid and we provide appropriate justification for using these items in the same section. In section 3.1, we provide more elaboration.}

\begin{tabular}{|c|c|c|}
\hline & & $\begin{array}{l}\text { Score of } 1 \text { is given if company } \\
\text { disclosed that }\end{array}$ \\
\hline \multirow{8}{*}{$\begin{array}{l}\text { Environment } \\
\text { performance }\end{array}$} & (1) ISO 14001 or EMS & $\begin{array}{lll}\text { Company } & \text { has } & \text { Environmental }\end{array}$ \\
\hline & & Management Systems (EMS) or ISO \\
\hline & & 14001. \\
\hline & (2) Greenhouse gas emission & $\begin{array}{l}\text { Company has taken action towards } \\
\text { reducing } \mathrm{CO}_{2}\end{array}$ \\
\hline & $\begin{array}{l}\text { (3) Energy efficiency or investing in } \\
\text { renewable technology }\end{array}$ & $\begin{array}{l}\text { Company has taken significant } \\
\text { measures to reduce its impact on } \\
\text { climate change and air pollution } \\
\text { through use of renewable energy and } \\
\text { clean fuels or through energy } \\
\text { efficiency. }\end{array}$ \\
\hline & (4) Water efficiency & $\begin{array}{l}\text { Company has accomplished a function, } \\
\text { task, process, or result with the minimal } \\
\text { amount of water usage. }\end{array}$ \\
\hline & (5) Waste management & $\begin{array}{l}\text { Company treated all materials as a } \\
\text { single class, whether solid, liquid, } \\
\text { gaseous, or radioactive substances, and } \\
\text { tried to reduce the harmful } \\
\text { environmental impacts of each through } \\
\text { different methods. }\end{array}$ \\
\hline & (6) Recycling & $\begin{array}{l}\text { Company is either a substantial user of } \\
\text { recycled materials as raw materials in }\end{array}$ \\
\hline
\end{tabular}


its manufacturing processes, or a major factor in the recycling industry

(7) New green products Company developed new products with low energy consumption or it has developed innovative products with environmental benefits.

\begin{tabular}{|c|c|c|}
\hline \multirow[t]{5}{*}{$\begin{array}{l}\text { Social } \\
\text { performance }\end{array}$} & (8) Education programs & $\begin{array}{l}\text { Company provided education and } \\
\text { training to its employees. }\end{array}$ \\
\hline & (9) Donation (existence) & $\begin{array}{l}\text { Company provided donation and any } \\
\text { financial support for community or any } \\
\text { NGO. }\end{array}$ \\
\hline & $\begin{array}{l}\text { (10) Donation (material amount } \\
\text { disclosed) }\end{array}$ & $\begin{array}{l}\text { Company's donation exceeds } 1.5 \% \text { of } \\
\text { income before tax. }\end{array}$ \\
\hline & (11) Community investment initiatives & $\begin{array}{l}\text { Company conducted any community } \\
\text { investment projects. }\end{array}$ \\
\hline & (12) Employees volunteering & $\begin{array}{l}\text { Employees were involved in the } \\
\text { community with the company's } \\
\text { encouragement and support by } \\
\text { contributing their time and skills. It is a } \\
\text { three-way partnership between the } \\
\text { employer, the employee, and the } \\
\text { beneficiary. }\end{array}$ \\
\hline
\end{tabular}

